\title{
A province with several climates: What knowledge of hydrology can be useful? A literature review
}

\author{
Andy M. Giler-Ormaza \\ Department of Hydraulic Engineering, Pontificia Universidad Católica del Ecuador, 130103 Portoviejo, Ecuador. \\ Autor para correspondencia: andygiler90@ hotmail.es \\ Fecha de recepción: 13 de agosto 2018 - Fecha de aceptación: 28 de agosto 2018
}

\begin{abstract}
This article explores the hydrological state of the art that could be useful for a climate-diverse region, such as Manabí province in Ecuador. The province, with an area of $18,940 \mathrm{~km}^{2}$, has a variety of tropical and dry climates. First, a review of the climatic conditions of the study area is carried out, since different sources disagree to some extent regarding climate types; then, a critical assessment of the relevant hydrologic literature is carried out. Here it is found that the literature best-suited for the conditions of Manabí includes literature for semi-arid, savannah and humid tropical hydrology. Several research gaps are found, but also a significant body of knowledge that could serve as a base for future studies. It should be noted that much of the available literature was obtained with vegetation and soil conditions that might differ from those of Manabí. Therefore, it is essential that findings from abroad are contrasted with results obtained in Manabí. Understanding of the hydrological functioning of the study area could contribute to the hydrologic literature for semi-arid, savannah and humid tropic climates.
\end{abstract}

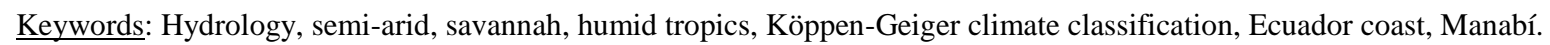

\section{RESUMEN}

El presente artículo explora el estado de la ciencia hidrológica que podría ser útil para una región con diversidad climática tal como lo es la provincia de Manabí en Ecuador. La provincia de Manabí, con un área de $18,940 \mathrm{~km}^{2}$, tiene una variedad de climas tropicales y secos. Primero, se lleva a cabo una revisión de las condiciones climáticas del área de estudio, ya que diferentes fuentes discrepan, en cierta medida, con respecto a los tipos de clima; luego, se lleva a cabo una evaluación crítica de la literatura hidrológica relevante. Aquí se encuentra que la literatura más adecuada para las condiciones de Manabí incluye literatura para hidrología semiárida, sabana y tropical húmeda. Aun cuando se encontró vacíos de investigación, también existe una cantidad significativa de conocimiento, utilizable como base en futuros estudios. Cabe señalar que gran parte de la literatura disponible se obtuvo con condiciones de vegetación y suelo que podrían diferir de las de Manabí. Por lo tanto, es esencial que resultados de otros sitios de estudio se contrasten con aquellos obtenidos en Manabí. El entendimiento del funcionamiento hidrológico en el área de estudio podría contribuir a la literatura de hidrología para climas semiárido, de sabana y tropical húmedo.

Palabras clave: Hidrología, semiárida, sabana, trópicos húmedos, clasificación climática Köppen-Geiger, costa de Ecuador, Manabí.

\section{INTRODUCTION}

Manabí is a province of $18,940 \mathrm{~km}^{2}$ located in Ecuador's coastal region. According to the recently updated KöppenGeiger classifications has Manabí at least three climates: semi-arid (BSh), savannah (Aw and As) and tropical monsoon (Am) (Peel, Finlayson, \& McMahon, 2007; Rubel \& Kottek, 2010). This situation is somewhat like that of other regions in the world: many climates within a small region. On the other hand, the situation in the study area is contrasted with some countries in Europe, which fall entirely or mostly within a single Köppen-Geiger classification, e.g. the UK, Belgium, The Netherlands and Poland.

Since Petheram et al. (2012) claim that most of the world's population growth to 2050 is projected to occur in the tropics, there is a serious need for robust methods for water resource assessments to underpin the sustainable management of water in these regions. Authorities need clear, visible and reliable information to be able to make well-informed decisions. In terms of water resources, having a variety of climates gives policy makers and practitioners more options, but at the same time, it can make management more challenging. Authorities ought more than ever before to make decisions based on scientific evidence. Unfortunately, at present, much of the evidence needed is not available, or has little visibility in Manabí and for regions with similar climates (Hughes, Heal, \& Leduc, 2017).

In general, not a great deal of scientific literature has been generated in Manabí, nor in Ecuador as a whole (Feyen, Mila, Van Hoof, Quinde, Ochoa, \& Bojorque, 2016; Sempertegui, Torres, Gallardo, \& Hernández, 1990). This also applies to the fields of hydrology, meteorology and ecology. Often, methods and models from temperate regions are employed without considering that these models could have been developed under different climatic conditions. The findings thus may not be 
applicable to Manabí and regions with similar climates. Furthermore, different sources of climatic information disagree to some extent with the climates in Manabí, making comparison with literature from other regions more challenging and less accurate. This creates confusion for researchers and practitioners.

The aim of this research is to review the hydrological state of the art that could be useful for a climate-diverse region like Manabí province in Ecuador. To achieve that, a review of the climatic conditions of the study area (Section 1) is first carried out; then, a critical assessment of the relevant hydrologic literature is conducted, highlighting gaps in research (Section 2).

\section{METHODS}

The literature review is based on local and international relevant scientific literature, government and NonGovernmental Organization (NGO) reports and press articles. Geographical Information Systems (GIS) were used to generate basic maps and figures, and when pictures were taken from other studies the source was acknowledged.

\section{STUDY AREA}

Manabí province is a province with an area of about 19,000 $\mathrm{km}^{2}$, located in Ecuador's coastal region, is traversed by the equatorial line $\left(0^{\circ} 0^{\prime} 0 "\right)$, and the El Niño (ENSO) and Humboldt currents are usually present. The elevation ranges from sea level on the Pacific Ocean coast to about 500 meters above sea level (m.a.s.l) in the easternmost part. The province is often subject to droughts and flooding. In order to overcome these issues, structural measures including dams, irrigation systems, and major flood protection schemes were put in place, starting in 1971 with the Poza Honda dam (OAS, Republica del Ecuador, CRM, INERHI, \& CONADE, 1991). Precipitation follows a roughly similar pattern to elevation, i.e. increasing from west to east. Nonetheless, strong rains can fall in most of the territory and flooding is an issue in many areas (Rossel, Goulven, Le, \& Cadier, 1999; Rossel, Cadier, \& Gomez, 1996). Regarding droughts, the plan has always been to convey water from the most humid areas in the east to the driest land in the west. While having a variety of climates on relatively such a small land area provides policy makers with more options; it also makes water resource management more challenging for them.

The largest urban areas are in the center and west of the province. Population is $1,369,780$ and is currently growing at a rate of $1.6 \%$ (INEC, 2010). Much of the territory is mountainous, and there are not many wide valleys in which flat land is available for agriculture and urbanization. Nonetheless, agricultural and livestock activities have taken place in the hills for many years; mainly in the small hills but also in the lower parts of the larger mountains. Land use is continuously shifting between and towards economic land uses (HernandezJimenez et al., 2017; INEC et al., 2012), what may place pressure on water resources management and natural disaster risk management.

\section{SECTION 1: THE CLIMATIC CONDITIONS OF MANABÍ}

\section{What are the climates in Manabi?}

To undertake an analysis of the province's hydrology, a review of its climates is first carried out. For this purpose, different sources of information are compared; among them: (i) a climate report prepared by Pourrut (1994) and the French institution of Development Research (IRD); (ii) the vegetation classification by Sierra (1999) (see Fig. 1); (iii) the updated Köppen-Geiger climate map by Peel et al. (2007) and Rubel \& Kottek (2010) (see Fig. 2a and 2b); and (iv) the climate map provided by the Ecuadorian national meteorological and hydrological institution INAMHI (Moya, 2006) (see Fig. 2c). Note that INAMHI's map is based on Thornthwaite's worldwide classification (Moya, 2006).

In the updated Köppen-Geiger map by Peel et al. (2007), several climates appear in Manabí province - some of which would be expected in a tropical region: savannah (Aw), tropical monsoon (Am); some of which would be expected in a dry region: semi-arid hot (BSh) or arid hot desert (Bwh); as well as others that are not expected for Manabí, since they correspond to temperate climates: dry and warm summer (Csb), dry winter and warm summer $(\mathrm{Cwb})$, and without dry season and warm summer $\mathrm{Cfb}$ ). With exception of the $\mathrm{Cfb}, \mathrm{Cwb}$, Csb and Bwh climates, the updated Köppen-Geiger information matches descriptions on the INAMHI's map and the information presented by Pourrut (1994). The Rubel \& Kottek (2010) map is similar to the Peel et al. (2007) map. However, the former does not show any temperate climate for Manabí. That source will be further discussed in more detail.

According to the Köppen-Geiger map by Rubel \& Kottek (2010), Manta is located in the BSh "arid steppe hot" (which might correspond to semi-arid), while Portoviejo is in the As "equatorial savannah with dry summer," Chone is in the Aw "equatorial savannah with dry winter," and the northeastern part of the province would correspond with the Am "equatorial monsoon." However, note that this map locates the main dam catchments within the savannah region. Errors of this type might be expected due to the map's global focus and the coarse size of the pixels. On the other hand, INAMHI's map has a better resolution and a more accurate representation of the climates in the province.

According to INAMHI, the easternmost Manabí area, in which part of the Daule Peripa dam basin is located, has a B3 r A' climate: "warm, humid, with no or small water excess." Moving westwards, in the areas of La Esperanza, Poza Honda, and the Río Grande catchment is the climate classified as C2 s A': "warm, sub-humid, with moderate water deficit in dry season." Chone, Calceta and part of Portoviejo fall within the C2 s2 A' climate, meaning "warm, sub-humid with major water deficit in dry season." Most of Portoviejo falls within the D d A' climate, which is "warm, dry with no or small water excess." Finally, in the westernmost part of Manabí, in Manta, climate is $\mathbf{E ~ d ~}$ A' which stands for "warm, arid with no or small water excess." Table 1 shows the meaning of each symbol on the INAMHI map. All figures were produced in Geographical Information Systems using data from the sources referred to above. Coordinates are projected local WGS84 $17 \mathrm{~s}$ format. 
(a)

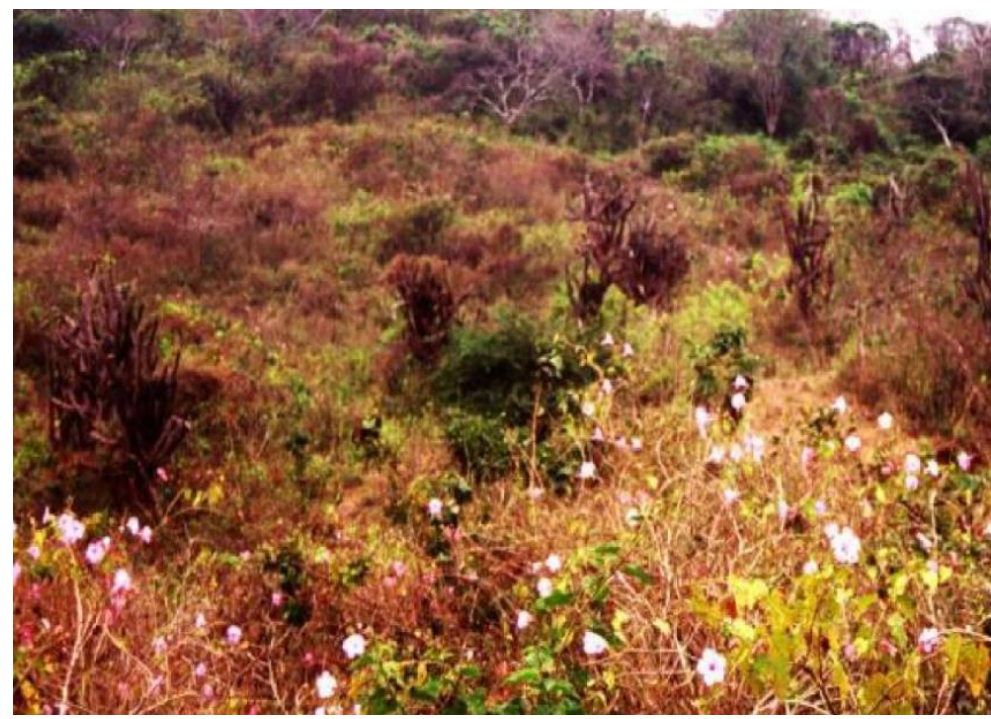

(b)

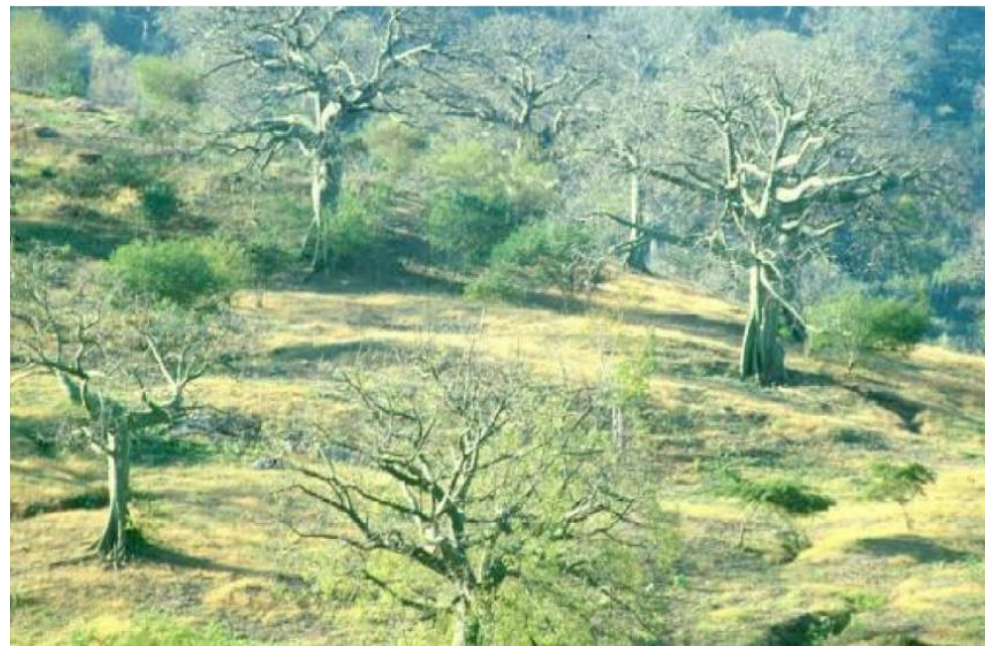

(c)

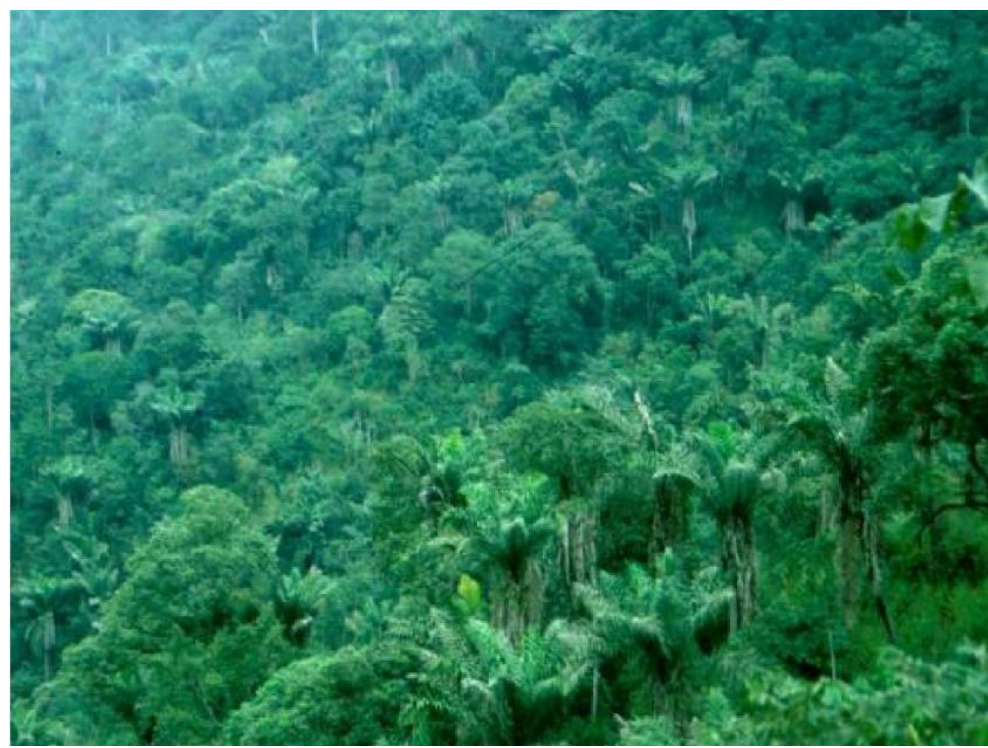

Figure 1. Three main classes of vegetation in Manabí (Source: Sierra, 1999): (a) Coastal dry shrubs in lowlands; (b) what is known as savannah; and (c) evergreen mountainous forest. These are considered to correspond with semi-arid, savannah and humid tropical climates, respectively. 
(a)

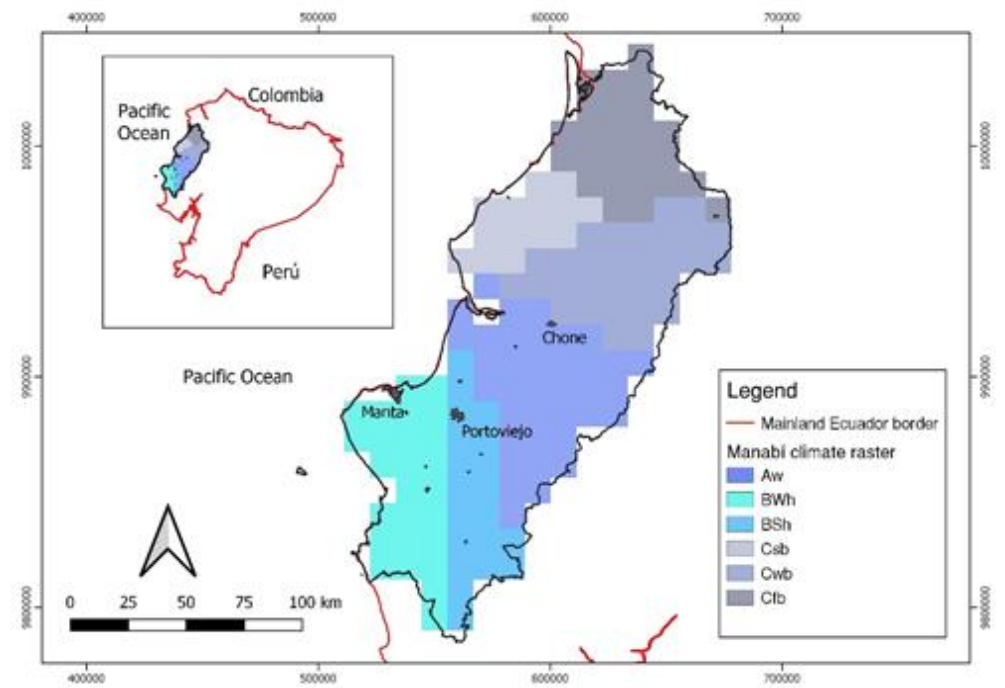

(b)

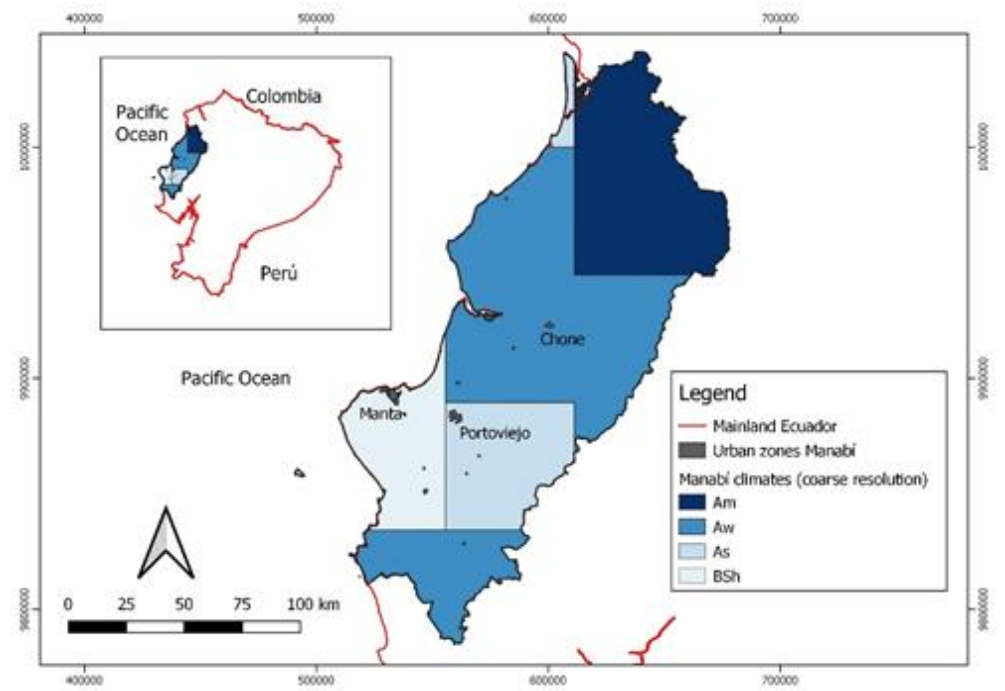

(c)

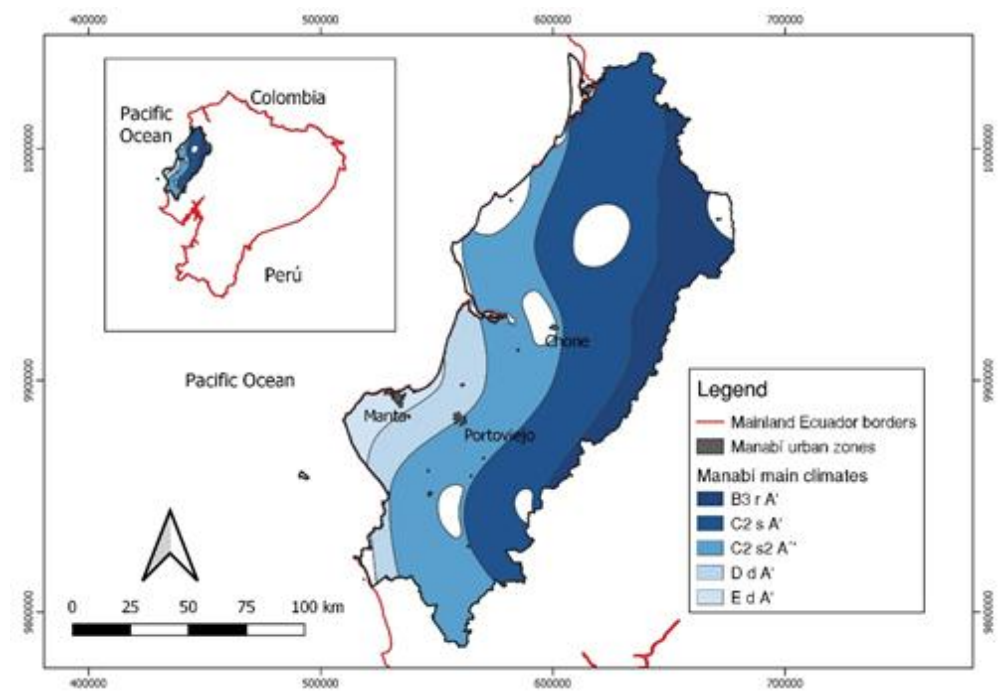

Figure 2. Main climates of Manabí province. (a) and (b) are the climates according to the updated Köppen-Geiger map by Peel et al. (2007) and Rubel \& Kottek (2010), respectively; (c) is the map presented by INAMHI (Moya, 2006) following the Thornthwaite classification. Notice that microclimates are not represented (left in blank) although they appear in the original INAMHI map. All figures were produced in Geographical Information Systems using data from the sources referred to above. Coordinates are projected local WGS 84 17s format. 
While the Thornthwaite criteria are widely used and the INAMHI map is more accurate, Köppen is commonly applied primarily for educational purposes (Peel et al., 2007) and it is, according to Kottek, Grieser, Beck, Rudolf, \& Rubel (2006), the most frequently used source in climate classification. Perhaps this is because many of the names are straightforward to remember. Matching Köppen-Geiger descriptions to a good extent, Sierra (1999) presented a vegetation classification in which Manabí has areas with mountainous humid tropical forest called "Bosque siempreverde piemontano". Here, it is considered that this could correspond with the Am climate class but also with a broader humid tropical forest classification (including Af). For this study, names similar to the Köppen-Geiger map are adopted, and Manabí is considered to have three main climates: Semi-Arid, corresponding with BSh; Savannah, including both Aw and As; and Humid tropical for Am. Selecting these three climates allows for a rapid comparison and review of the literature generated throughout the world in similar climatic areas.

According to Pourrut (1994) the region around Manta may have less than $200 \mathrm{~mm}$ of rainfall per year, most of it concentrated in the period December to April. According to Köppen-Geiger maps, this corresponds to the semi-arid and arid climate. Moving eastward from the Pacific Ocean, between 200 and $400 \mathrm{~mm} /$ year is the mean rainfall around Portoviejo, located on the border between the drier Manta climate and the relatively more humid climate of the savannah. From Portoviejo, there is a marked transition in rainfall within few kilometers. Two categories are found moving eastwards towards the Daule Peripa dam catchment. Rainfall changes to a range of 400 to 1,300 $\mathrm{mm} / \mathrm{year}$ in a region that includes the surroundings of Chone, and then from 1,300 to 3,000 mm/year in the Daule Peripa catchment itself. This might correspond to a third category of climate (humid tropical) located further east, near to the boundaries with the Los Ríos, Santo Domingo and Guayas provinces.

Table 1. Definition of INAMHI climate map symbols (Source: Moya, 2006).

\begin{tabular}{|c|c|}
\hline \multicolumn{2}{|c|}{ Water Regime Index } \\
\hline Symbol & Definition \\
\hline A & Super humid \\
\hline B3 & Humid \\
\hline $\mathrm{C} 2$ & Sub-humid \\
\hline $\mathrm{D}$ & Dry \\
\hline $\mathrm{E}$ & Arid \\
\hline \multicolumn{2}{|c|}{ Seasonal Water Variation } \\
\hline Symbol & Definition \\
\hline $\mathrm{r}$ & No or small water deficit \\
\hline $\mathrm{s}$ & $\begin{array}{l}\text { Moderate water deficit in dry } \\
\text { season }\end{array}$ \\
\hline s2 & Major water deficit in dry season \\
\hline W & $\begin{array}{l}\text { Moderated water excess in rainy } \\
\text { season }\end{array}$ \\
\hline $\mathrm{d}$ & No or small water excess \\
\hline \multicolumn{2}{|c|}{ Temperature Regime } \\
\hline Symbol & Definition \\
\hline $\mathrm{A}^{\prime}$ & Warm \\
\hline $\mathrm{B}^{\prime} 4$ & Semi-warm or mild warm \\
\hline B'3 & Warm temperate \\
\hline B'2 & Cold temperate \\
\hline B'1 & Semi-cold or mild cold. \\
\hline
\end{tabular}

The mean annual temperature ranges from 18 to 24 degrees Celsius. There is not a marked transition in the temperature observed from east to west, but rather a difference between two categories: (1) the hottest area near the coast and in the valleys, where Manta, Portoviejo and Chone are located, at around 24 degrees Celsius; and (2) near 18 degrees Celsius in the mountainous areas where, for instance, Jipijapa is located.

\section{SECTION 2: CRITICAL SURVEY OF RELEVANT LITERATURE}

\section{Semi-arid hydrology}

The hydrology of semi-arid regions differs substantially from that of the more-studied temperate climates (Simmers, 2003). Rivers in those regions are ephemeral and many hydrological processes are not continuous or non-linear, whilst rivers in temperate regions tend to be perennial (García-Pintado, Barberá, Erena, \& Castillo, 2009). Hortonian overland flow -also known as infiltration excess overland flow (IEOLF)- is believed to have the greatest contribution to the runoff in semi-arid regions, which is not the case in temperate regions (Bull, Kirby, Shannon, \& Hooke, 2000). This implies that in semi-arid regions, hydrographs tend to be single-peaked and flashy, as IEOLF has been proven to be the type of runoff that reaches channels first (Camarasa-Belmonte, 2016). Because of IEOLF, erosion and sediment generation and transport processes are also accelerated in these regions. Sediment transport processes are especially relevant because they have an influence on flood risk and on the area's geomorphology (Bull \& Kirkby, 2002). However, there are uncertainties in the knowledge of the semi-arid hydrological processes, and some physicallybased models developed in temperate catchments have been reported to be unsuccessful in semi-arid catchments (García-Pintado et al., 2009).

There are also other information gaps in terms of the hydrology and geomorphology of semi-arid areas. For instance, the extent to which IEOLF contributes to runoff in semi-arid regions has been challenged by recent studies, such as that conducted by van Schaik, Schnabel, \& Jetten (2008) who found that subsurface "preferential flow" takes place in semi-arid regions under certain circumstances. Regarding the river geomorphology some authors found that every 10 years a cross-section-changing event occurs (Bull \& Kirkby, 2002). However most of this research was conducted in a region not directly influenced by El Niño: i.e., Spain. Knowing the shape, a river will take is essential for populations living near rivers, in terms of their wellbeing and property insurance. Hydrology and geomorphology topics in semi-arid regions therefore need further research.

While in temperate regions hydrological modelling is used to analyze and understand hydrological processes, in semiarid catchments modelling is seldom applied since there are issues that not yet have been solved or that have proved difficult to overcome. For instance, because many hydrological processes are not continuous, runoff is complicated to measure and study. In semi-arid catchments, the influence of "transmission losses" is related to these discontinuities (Dunkerley \& Brown, 1999). Financial and logistics constraints may be two additional reasons why semi-arid hydrological processes 
are less documented (Simmers, 2003). About logistics, research in semi-arid regions run into difficulties with establishing monitoring networks. This is partially because most significant rainfall events are very heterogeneous in space and time. In addition, problems such as personal safety and equipment robbery are common (Bull \& Kirkby, 2002). Further, many measuring devices have been destroyed when flooding occurs (Maneta, Schnabel, \& Jetten, 2008). In many cases, lack of knowledge in semi-arid regions does not allow to accurately mimic river discharges by hydrological models, thus placing constraints on the work of local practitioners. There are several published studies that have demonstrated the lack of accuracy when attempting rainfall-runoff modelling in semi-arid and arid regions. Relevant model parameters are often not calibrated and high-quality data is generally not available. Neither is there any agreement in the literature as to which models give better results: empirical, semi-empirical or the more complex distributed models (McIntyre \& Al-Qurashi, 2009). For instance, a study carried out in a catchment in Oman found poor prediction performance in most cases and higher-thanexpected uncertainty (Al-Qurashi, McIntyre, Wheater, \& Unkrich, 2008). Based on the experience of these authors, the effort of using complex models is not justified for semi-arid and arid regions. A study using 10 rainfallrunoff models (McIntyre \& Al-Qurashi, 2009) and a study in the US (Yatheendradas et al., 2008) also found poor results and high uncertainties in rainfall-runoff modelling. Given that hydrological modelling may not be accurate enough, hydraulic modelling should be considered as an option that could provide a good solution, or a complimentary one.

\section{Savannah hydrology}

Among all the literature on hydrology, the development of savannah climate hydrology is unique. Since it shows similarities with semi-arid climates -such as those found around the Mediterranean Sea- many authors have tried to extend the principles of the semi-arid hydrological processes to savannah catchments. In a similar practice, literature from more humid tropical river basin studies has been applied in savannah research because savannahs are, by definition, located in the tropics (Smith \& Smith, 2007). Those attempts probably took place because of the lack of previous studies. Researchers tried to use existing or available literature to guide/refine their research questions, and/or to provide a framework for their research results.

Both semi-arid and savannah environments are characterized by water scarcity and ephemeral rivers. The precipitation is concentrated mostly or completely during a few months, while the rest of the year there is a lack of rainfall (Smith \& Smith, 2007). Most savannah catchments are in developing countries, such as those of sub-Saharan Africa, and South America, except for Australia. These countries still lack extensive monitoring networks for hydrometeorological data collection (Petheram et al., 2012). In general, a backlog of hydrological research exists in these regions. Nevertheless, few, yet important, efforts have been made by institutions such as ORSTROM (now IRD) and SCIRO. They have formed much of the basis for the existing knowledge and outlined certain research paths.

Despite the similarities between semi-arid and savannah, a few important differences exist that ultimately affect the hydrological processes. Farrick \& Branfireun (2014), found that semi-arid vegetation species have a type of waxy layer covering their leaves. This has not been found for savannah plants. Furthermore, the crusting patterns found on semi-arid soils are not reported on savannah soils. Both findings suggest an increase in the imperviousness of the surface layers with which rainfall interacts in the first place. This has been called "repellency", and Farrick (2014) argues that frequent fires -which take place in semi-arid "Mediterranean" regionsincrease this property. The low density of vegetation cover in semi-arid regions is also believed to be highly influential. Therefore, interactions of rainfall with canopy and soil surface could be expected to lead to different processes in terms of runoff production. Several studies have yet to confirm these findings and, as such, they should be taken with caution. Nevertheless, they raise awareness that differences between BSh and Aw-As can exist and could have an influence on the hydrological processes, and that more thorough research is needed. More attention from the scientific community could lead to stronger conclusions.

Despite the notable contribution to the body of knowledge by Australian authors, the applicability of their results could be inappropriate for Manabí. Although certain soil characteristics could be similar (Cook et al., 1998), swelling clays can be found in both environments, there are also certain differences to consider. The slopes in the Australian wet-dry tropics are reported to be generally low. In Manabí's Aw-As region, in contrast, the landscape is dominated by hills and valleys. Also, Australia's dry evergreen environments differ significantly from its deciduous or semi-deciduous counterparts from the Americas -e.g., those in parts of Mexico and Manabí (see Fig. 3). In Australia, forests are evergreen because of soil infertility and the high cost of producing new leaves. Higher air temperatures are believed to favor the growth of evergreen trees. In addition, the soil composition (coarse) and the soil depth (shallow), together with the geological setting, cause water to be retained in an area above the impermeable layer, which can easily be reached by the evergreen tree roots (Bowman \& Prior, 2005). In contrast, the soils in the Manabí savannah region are deeper and more fertile, which may explain the feasibility of yearly leaf production (Smith \& Smith, 2007). For AsAw areas, it has been shown that having vegetation cover, even if only in patches, can obstruct runoff reducing soil and water losses. Water infiltration in the soil is likely to increase (Bartley et al., 2006). Because of these differences in land cover and canopy interactions with rainfall, runoff in Manabí and Australia can vary significantly.

Similar to the leaf and crusting uncertainty, there is no strong comparison between BSh and Aw-As in terms of connectivity and transmission losses. While there are some findings on transmission losses from the semi-arid counterpart, something similar could occur in savannah catchments. One study compelling a significant number of research concludes that, in some cases, "water losses are considerable" (Dubreuil, 1985). In addition, the characteristics of the storms bringing rainfall to savannah basins may be different from those of semi-arid basins. Surface runoff does not occur with much frequency in AwAs environments. Some savannah catchments behave the same as temperate catchments in that specific thresholds of antecedent water storage and rainfall amounts are found prior to the start of runoff. Nonetheless, according to 
Farrick \& Branfireun (2013), "these remain completely undescribed, both empirically and conceptually, in tropical dry forest catchments".

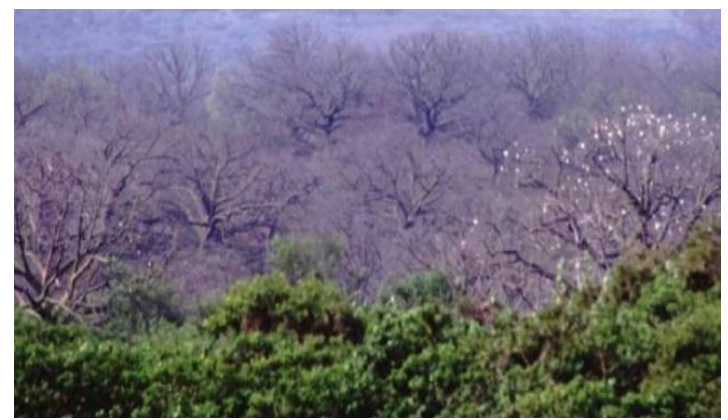

(a)

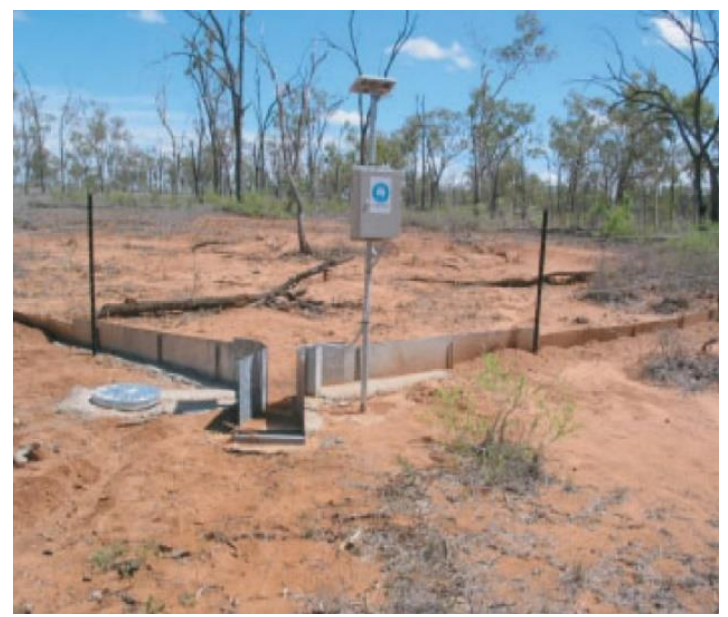

(b)

Figure 3. Comparisons of (a) Manabí savannah (Aw and As), and (b) Australia savannah (Sources: Sierra, 1999; Bartley et al., 2006).

To further complicate research activities, savannah climates can have different names in different parts of the world, and local researchers write their reports using those names. For instance, in Brazil and in parts of South America they can be called Cerrado, Caatinga, Llanos or Dry Chaco; while in Australia, they are referred to as "wet/dry tropics," or Dry Evergreen. It is curious that some Brazilian authors have referred to their study areas simply as "semi-arid" (Montenegro \& Ragab, 2010; de Araújo \& González, 2009). Perhaps this is done to place results in a wider context, although it fails to consider the differences that can exist. Studies in Mexico have referred to savannah catchment as "dry tropical" or "tropical deciduous" forests (Farrick \& Branfireun, 2014; Vose \& Maass, 1999). Furthermore, many studies have been written in French, Spanish or Portuguese, making them less visible for researchers from the primarily English-writing hydrological community.

Another environment in which to seek out Aw-As literature is in Sub-Saharan Africa. Findings there could provide interesting insights into the hydrology of savannah environments in general. For instance, in a study by Chevallier \& Planchon (1993), it was found that all the primary known runoff generating processes take place in a savannah river basin. These include variable source area, Hortonian Overland Flow (HOLF), Saturation Excess
Overland Flow (SEOLF), soil pipes, preferential flow, throughflow, and return flow. Considering this, certain comparisons would be permissible.

\section{Humid tropic hydrology}

Compared with its counterparts in temperate regions, there is a sizable knowledge gap regarding the hydrology of humid tropics, including the hydrology of tropical rainforest (TRF). In particular, little is known about the potential changes in the evapotranspiration and runoff generation patterns which might result from human activities in these environments (Wohl et al., 2012). There is also a need to determine the magnitudes of water fluxes and the residence times of water in the soil. Until today, it is known that a large part of the key event processes take place in the soil and in the forest canopy (Ward \& Robinson, 2000).

With respect to the forest canopy, the layer can be regarded as a water reservoir. The canopy has a capacity for interception and storage of precipitation, either in the form of rain or mist (called horizontal precipitation) (Cavelier \& Goldstein, 1989), and plays a particularly important role in TRF. The canopy also has an influence in/on the evapotranspiration processes (Wohl et al., 2012). Individual canopy characteristics control the quantities and qualities of water temporarily stored in this layer (Fleischbein, Wilcke, Valarezo, Zech, \& Knoblich, 2006), as well as the quantities and qualities of water that reach the soil through the branches, leaves and stems; also called "throughfall" (Bruijnzeel, 1990). Challenges to the measurement and quantification of water movements through these layers exist.

Before the water reaches the ground, it may interact with a layer of fallen leaves and branches accumulated on the ground's surface, called the litter layer. This layer can be considered a small reservoir that gradually releases water during the dry season. However, there are uncertainties regarding litter hydrology of TRF with respect to the water holding capacity and the drainage rate. Most of the available literature is based on studies in regions with temperate climates. An interesting finding by $\mathrm{Li}, \mathrm{Niu}, \&$ Xie (2014) is that the litter layer reduces the runoff volume, produces a lag in the onset of runoff, and minimizes soil loss. In a tropical region, Park, Friesen, \& Serrud (2010) carried out data collection and analysis in a setting with primarily commercial species that might not be found in Manabí. In many temperate and tropical regions, the accumulation of leaves might not occur in the same way as it does in Manabí's humid forests, which probably is due to the differences in tree species.

While the forest canopy and the litter layer can have the function of protecting the soil from erosive processes, it can also hamper the generation of runoff as infiltration excess overland flow (Shaw, Beven, Chappel, \& Lamb, 2010). Hortonian flow is often believed to have little relevance in forest environments, including humid tropical trees (Ward \& Robinson, 2000), although its occurrence has been seen in association with steep slopes where natural vegetation has been cut, exposing the shallow soil (Campling, Gobin, Beven, \& Feyen, 2002). However, there is still not enough literature or evidence to support the current state of knowledge. In fact, Bruijnzeel (2001) and Wohl et al. (2012) suggest that one of the most important knowledge gaps are the effects of the deforestation of tropical forests. All this invites us to carry 
out research in fields where there are still processes to be understood.

The precipitation that has not been retained in the canopy layer, or in the litter layer, infiltrates. The interactions of water in the soil are diverse since, hydrologically speaking, there are many paths that the water can take (Ward \& Robinson, 2000). Quantities of water can remain in the organic horizons (A, B and h) and return to the surface in short periods of time. Other quantities can penetrate towards the $\mathrm{C}$ horizon and return to the surface in longer periods of time and in geographic locations very distant from the initial location (Shaw et al., 2010). These interactions are in turn related to other runoff generation mechanisms, including the saturation excess overland flow (SEOF) and flow through "natural pipes" or "pipes" (Chappell, 2010). With respect to natural pipelines in TRF soils, there are still gaps in knowledge, justifying more indepth studies about the true influence of the flows by natural pipes. According to Chappell (2010) it is necessary to quantify the lengths and dimensions of "natural pipe" networks and the mechanisms recharging these pipe networks.

Compared to the number of publications from temperate regions, few studies have been conducted in tropical humid areas around the globe. However, the experiences of Kinner \& Stallard (2004), Campling et al. (2002), and Molicova, Grimaldi, Bonell, \& Hubert (1997) are illustrative for good practice. In their studies, from different regions of the globe, they used hydrological modeling to determine the processes of runoff generation. Similarly, Chappell, Franks, \& Larenus (1998) used hydrological modeling to determine soil properties that influence the runoff generation processes.

Regarding research on the hydrology of tropical humid forests in Ecuador, to the author's knowledge, thus far studies have primarily been located in the eastern and western Andes mountain range (e.g. Fleischbein et al., 2006; Boy, Valarezo, \& Wilcke, 2008; Crespo et al., 2012; Goller et al., 2005). However, for Manabí, no studies have been found that attempt to describe or analyze the hydrological processes of tropical humid forests, let alone which attempt to specifically understand the processes of runoff generation. It is hereby recommended that studies on these topics be carried out.

\section{CONCLUSIONS}

For this study, names similar to the Köppen-Geiger map are adopted and Manabí is considered to have three climates: semi-arid, corresponding to BSh; savannah, including both Aw and As; and Am humid tropical climate. Selecting these three allows for a rapid comparison and review of the global literature in similar climate areas. Some areas in which focus might be prioritized are discussed below.

There is literature available for use in Manabí's semi-arid region. Significant progress has been made elsewhere, mostly in Mediterranean areas. Since there might be differences between semi-arid Mediterranean catchments and Manabí BSh catchments -mostly in the soil and vegetation species- more research is needed to determine whether these findings could be applied in Manabí's semiarid region. Perhaps the main issue to be tackled are the difficulties faced in the establishment of monitoring networks. Rainfall satellite data and remote sensing technologies should be employed where possible. Given that hydrological modelling may not be accurate enough, hydraulic modelling should be considered as an option that could provide a good solution, or a complementary solution, in obtaining flow rate data. Nonetheless, rainfallrunoff modelling is not discouraged. Some efforts could be made in Manabí before this option is discarded.

For the savannah region of Manabí, there are also many gaps to be filled. Here a call for caution is necessary, as many authors have tried to extend the principles of the semi-arid and humid tropical hydrological processes to savannah catchments. On the other hand, while some savannah literature from other regions -such as Africa and México- could be of use, given the differences outlined in the manuscript, findings in Australia might have their limitations. Perhaps the main point to investigate is whether Manabí semi-arid vegetation and soils have characteristics different than the Manabí savannah counterparts, which could lead to an increase in the imperviousness of the catchments. Here it is agreed with other authors that researchers should adopt one name for their findings regarding savannah climates, rather than reporting with different names such as "cerrado" or "caatinga."

Regarding Manabí's humid tropic hydrology, including tropical rainforest (TRF), there is a growing body of knowledge emerging from similar regions elsewhere around the globe which could be of use here. Nonetheless, given the potential differences between tree and shrub species found in Manabí and those found elsewhere, studies in Manabí must be carried out. Given the strong seasonality of rainfall in Manabí and the orographic effect, it is believed that many of Manabí's TRF remain green because of the interception from clouds and mist in the mountainous areas. Attention should thus be given to the interception of water from mist and clouds together, especially in the quantification of this interception. Finally, given the land use change, another important area of focus is the effects on the dry season flow or on the total amount of water that may arise not only because of the deforestation of tropical forests, but also of their deciduous dry counterparts.

Thanks to having three climates in a relatively small region, Manabí could be regarded as a laboratory for hydrological research. It is evident that findings obtained in Manabí could also be applied to other regions with similar characteristics.

\section{ACKNOWLEDGMENTS}

Some ideas presented in this manuscript are also found in the author's M.Sc. dissertation at the University of Leeds, UK. The author would like to thank M. Zamora and L. Reyna for their constructive comments on the late stages of the manuscript and to R. Cusme and M. Alcivar for providing support with the images. 


\section{REFERENCES}

Al-Qurashi, A., McIntyre, N., Wheater, H., \& Unkrich, C. (2008). Application of the Kineros2 rainfall-runoff model to an arid catchment in Oman. Journal of Hydrology, 355(1-4), 91-105. https://doi.org/10.1016/j.jhydrol.2008.03.022

Bartley, R., Roth, C. H., Ludwig, J., McJannet, D., Liedloff, A., Corfield, J., ... Abbott, B. (2006). Runoff and erosion from Australia's tropical semi-arid rangelands: influence of ground cover for differing space and time scales. Hydrological Processes, 20(15), 3317-3333. https://doi.org/10.1002/hyp.6334

Bowman, D. M. J. S., \& Prior, L. D. (2005). Why do evergreen trees dominate the Australian seasonal tropics? Australian Journal of Botany, 53(5), 379-399. https://doi.org/10.1071/BT05022

Boy, J., Valarezo, C., \& Wilcke, W. (2008). Water flow paths in soil control element exports in an Andean tropical montane forest. European Journal of Soil Science, 59(6), 1209-1227.

https://doi.org/10.1111/j.1365-2389.2008.01063.x

Bruijnzeel, L. (1990). Hydrology of moist tropical forests and effects of conversion: A state of knowledge review. Paris, France: Unesco.

Bruijnzeel, L. (2001). Hydrology of tropical montane cloud forest: A reassessment. Land Use and Water Resources Research, 1(1.1), 1-18.

Bull, L., \& Kirkby, M. (2002). Dryland rivers: Hydrology and geomorphology of semi-arid channels. England: Wiley.

Bull, L., Kirkby, M., Shannon, J., \& Hooke, J. (2000). The impact of rainstorms on floods in ephemeral channels in southeast Spain. CATENA, 38(3), 191-209. https://doi.org/10.1016/S0341-8162(99)00071-5

Camarasa-Belmonte, A. M. (2016). Flash floods in Mediterranean ephemeral streams in Valencia Region (Spain). Journal of Hydrology, 541, 99-115. https://doi.org/10.1016/j.jhydrol.2016.03.019

Campling, P., Gobin, A., Beven, K., \& Feyen, J. (2002). Rainfall-runoff modelling of a humid tropical catchment: The TOPMODEL approach. Hydrological Processes, 16(2), 231-253. https://doi.org/10.1002/hyp.341

Cavelier, J., \& Goldstein, G. (1989). Mist and fog interception in elfin cloud forests in Colombia and Venezuela. Journal of Tropical Ecology, 5(3), 309-322. https://doi.org/10.1017/S0266467400003709

Chappell, N. A. (2010). Soil pipe distribution and hydrological functioning within the humid tropics: A synthesis. Hydrological Processes, 24(12), 1567-1581. https://doi.org/10.1002/hyp.7579

Chappell, N. A., Franks, S. W., \& Larenus, J. (1998). Multi-scale permeability estimation for a tropical catchment. Hydrological Processes, 12(9), 1507-1523. https://doi.org/10.1002/(SICI)10991085(199807)12:9<1507::AID-HYP653>3.0.CO;2-J

Chevallier, P., \& Planchon, O. (1993). Hydrological processes in a small humid savanna basin (Ivory Coast). Journal of Hydrology, 151(2-4), 173-191. https://doi.org/10.1016/0022-1694(93)90235-2

Cook, P. G., Hatton, T. J., Pidsley, D., Herczeg, A. L., Held, A., O'Grady, A., \& Eamus, D. (1998). Water balance of a tropical woodland ecosystem, Northern Australia: A combination of micro-meteorological, soil physical and groundwater chemical approaches. Journal of Hydrology, 210(1-4), 161-177. https://doi.org/10.1016/S0022-1694(98)00181-4

Crespo, P., Bücker, A., Feyen, J., Vaché, K. B., Frede, H. G., \& Breuer, L. (2012). Preliminary evaluation of the runoff processes in a remote montane cloud forest basin using Mixing Model Analysis and Mean Transit Time. Hydrological Processes, 26(25), 3896-3910. https://doi.org/10.1002/hyp.8382

de Araújo, J., \& González, J. (2009). Comparative hydrology: analysis of a semiarid and a humid tropical watershed. Hydrological Processes, 23(1), 1169-1178. https://doi.org/10.1002/hyp.7232

Dubreuil, P. (1985). Rreview of field observation of runoff generation., 80 .

Dunkerley, D., \& Brown, K. (1999). Flow behaviour, suspended sediment transport and transmission losses in a small (sub-bank-full) flow event in an Australian desert stream. Hydrological Processes, 13(11), 15771588. https://doi.org/10.1002/(SICI)10991085(19990815)13:11<1577::AID-HYP827>3.0.CO;2L

Farrick, K. K. (2014). Runoff generation in a tropical dry forest watershed: Processes, patterns and connectivity. Doctoral thesis, The University of Western Ontario, Canada. Retrieved from

http://ir.lib.uwo.ca/etd/2523\%5Cnhttp://ir.lib.uwo.ca/cg i/viewcontent.cgi?article $=4003 \&$ context $=$ etd $\% 5$ Cnhttp: //ir.lib.uwo.ca/etd/2523/

Farrick, K. K., \& Branfireun, B. A. (2013). Left high and dry: A call to action for increased hydrological research in tropical dry forests. Hydrological Processes, 27(22), 3254-3262. https://doi.org/10.1002/hyp.9935

Farrick, K. K., \& Branfireun, B. A. (2014). Infiltration and soil water dynamics in a tropical dry forest: It may be dry but definitely not arid. Hydrological Processes, 28(14), 4377-4387. https://doi.org/10.1002/hyp.10177

Feyen, J., Milia, M., Van-Hoof, H., Quinde, K., Ochoa, V., \& Bojorque, J. (2016). Improving the publication visibility of Ecuador' s higher education system, Maskana, 7(2), 113-125.

Fleischbein, K., Wilcke, W., Valarezo, C., Zech, C., \& Knoblich, K. (2006). Water budgets of three small catchments under montane forest in Ecuador: experimental and modelling approach. Hydrological Processes, 20(1), 2491-2507. https://doi.org/10.1002/hyp.6212 Water

García-Pintado, J., Barberá, G. G., Erena, M., \& Castillo, V. M. (2009). Calibration of structure in a distributed forecasting model for a semiarid flash flood: Dynamic surface storage and channel roughness. Journal of Hydrology, 377(1-2), 165-184. https://doi.org/10.1016/j.jhydrol.2009.08.024

Goller, R., Wilcke, W., Leng, M. J., Tobschall, H. J., Wagner, K., Valarezo, C., \& Zech, W. (2005). Tracing water paths through small catchments under a tropical montane rain forest in south Ecuador by an oxygen isotope approach. Journal of Hydrology, 308(1-4), 6780. https://doi.org/10.1016/j.jhydrol.2004.10.022

Hernandez-Jimenez, A., Vera-Macias, L., NavedaBasurto, C., Guzman-Cedeno, A., Vivar-Arrieta, M., Zambrano, T., ... Lopez-Alava, G. (2017). Variaciones 
en algunas propiedades del suelo por el cambio de uso de la tierra, en las partes media y baja de la microcuenca Membrillo, Manabi, Ecuador. Cultivos Tropicales, 38(1), 50-56. Retrieved from http://scielo.sld.cu/scielo.php?script=sci_arttext\&pid=S 0258-

59362017000100006\&lng=en\&nrm=iso.com\&tlng=es

Hughes, D., Heal, K., \& Leduc. (2017). Improving the visibility of hydrological sciences from developing countries. Hydrological Sciences Journal - Journal Des Sciences Hydrologiques, 59(9), 1627-1635. https://doi.org/10.1080/02626667.2014.938653

INEC. (2010). Resultados del de población y vivienda Censo 2010 en el Ecuador. Retrieved from http://www.ecuadorencifras.gob.ec/wpcontent/descargas/Manu-lateral/Resultadosprovinciales/manabi.pdf

INEC, Naranjo, L., Chaves, R., Salazar, D., Orejuela, D., Cuichán, M., ... Villafuerte. (2012). Encuesta de superficie y producción agropecuaria continua 2012. Inec. Retrieved from http://www.ecuadorencifras.gob.ec/documentos/webinec/Estadisticas_agropecuarias/espac/espac_2012/Info rmeEjecutivo.pdf

Kinner, D. A., \& Stallard, R. F. (2004). Identifying storm flow pathways in a rainforest catchment using hydrological and geochemical modelling. Hydrological Processes, 18(15), 2851-2875. https://doi.org/10.1002/hyp.1498

Kottek, M., Grieser, J., Beck, C., Rudolf, B., \& Rubel, F. (2006). World map of the Köppen-Geiger climate classification updated. Meteorologische Zeitschrift, 15(3), 259-263. https://doi.org/10.1127/09412948/2006/0130

Li, X., Niu, J., \& Xie, B. (2014). The effect of leaf litter cover on surface runoff and soil erosion in Northern China. PLoS ONE, 9(9). https://doi.org/10.1371/journal.pone.0107789

Vose, J. M., \& Maass, J. M. (1999). Comparative nalysis of hydrologic responses of tropical deciduous and temperate deciduous watershed to climatic change. In: C. Aguirre-Bravo, F. C. Rodriguez (Eds.). North American science Symposium: toward a unified framework for inventorying and monitoring forest ecosystem resources; 1998 November 2-6; Guadalajara, Mexico. Proceedings RMRS-P-12. Fort Collins, CO: U.S. Department of Agriculture, Forest Service, Rocky Mountain Research Station: 292-298

Maneta, M., Schnabel, S., \& Jetten, V. (2008). Continuous spatially distributed simulation of surface and subsurface hydrological processes in a small semiarid catchment. Hydrological Processes, 22(13), 2196-2214. https://doi.org/10.1002/hyp.6817

McIntyre, N., \& Al-Qurashi, A. (2009). Performance of ten rainfall-runoff models applied to an arid catchment in Oman. Environmental Modelling and Software, 24(6), 726-738.

https://doi.org/10.1016/j.envsoft.2008.11.001

Molicova, H., Grimaldi, M., Bonell, M., \& Hubert, P. (1997). Using Topmodel towards identifying and modeling thehydrological patterns within a headwater,humid, tropical catchment. Hydrological Processes, 11(April 1996), 1169-1196.
Montenegro, A., \& Ragab, R. (2010). Hydrological response of a Brazilian semi-arid catchment to different land use and climate change scenarios: A modelling study. Hydrological Processes, 24(19), 2705-2723. https://doi.org/10.1002/hyp.7825

Moya, R. (2006). Climas del Ecuador. Quito, Ecuador: INAMHI. Retrieved from http://186.42.174.231/gisweb/METEOROLOGIA/CLI MATOLOGIA/Climas del Ecuador 2006.pdf

OAS, Republica del Ecuador, CRM, INERHI, \& CONADE. (1991). Plan integral de desarrollo de los recursos hídricos de la Provincia de Manabi. Washington, D.C. Retrieved from https://www.oas.org/DSD/publications/Unit/oea40s/beg in.htm\#Contents

Park, A., Friesen, P., \& Serrud, A. A. S. (2010). Comparative water fluxes through leaf litter of tropical plantation trees and the invasive grass Saccharum spontaneum in the Republic of Panama. Journal of Hydrology, 383(3-4), 167-178. https://doi.org/10.1016/j.jhydrol.2009.12.033

Peel, M. C., Finlayson, B. L., \& McMahon, T. A. (2007). Updated world map of the Köppen-Geiger climate classification. Hydrology and Earth System Sciences, 11(5), 1633-1644. https://doi.org/10.1127/09412948/2006/0130

Petheram, C., Rustomji, P., McVicar, T. R., Cai, W., Chiew, F. H. S., Vleeshouwer, J., ... Perraud, J.-M. (2012). Estimating the impact of projected climate change on runoff across the tropical savannas and semiarid rangelands of Northern Australia. Journal of Hydrometeorology, 13(2), 483-503. https://doi.org/10.1175/JHM-D-11-062.1

Pourrut, P. (1994). L'eau en Equateur: principaux acquis en hydroclimatologie. Paris, France: ORSTOM. Retrieved from https://core.ac.uk/download/pdf/39856198.pdf

Rossel, F., Cadier, E., \& Gomez, G. (1996). Las inundaciones en la zona costera ecuatoriana: causas; obras de proteccion existentes y previstas. Bulletin de l'Insitut Français d'Études Andines, XXV, 3, (January 1996), 339-420.

Rossel, F., Goulven, P. Le, \& Cadier, E. (1999). Répartition spatiale de l'influence de l' ENSO sur les précipitations annuelles en Equateur. Revue des Sciences de l'Eau, 12(1), 183-200. https://doi.org/10.7202/705348ar

Rubel, F., \& Kottek, M. (2010). Observed and projected climate shifts 1901-2100 depicted by world maps of the Köppen-Geiger climate classification. Meteorologische Zeitschrift, 19(2), 135-141. https://doi.org/10.1127/0941-2948/2010/0430

Sempertegui, J., Torres, G., Gallardo, G., \& Hernández, A. (1990). Estado actual del desarrollo de la Ciencia y Tecnología en el Ecuador. Retrieved from http://repositorio.educacionsuperior.gob.ec/bitstream/2 8000/993/1/T-SENESCYT-0199.pdf

Shaw, E., Beven, K., Chappel, N., \& Lamb, R. (2010). Hydrology in practice ( $4^{\text {th }}$ ed.). CRC Press.

Sierra, R. (1999). Propuesta preliminar de un sistema de clasificación de vegetación para el Ecuador Continental. Retrieved from http://www.academia.edu/2081344/Propuesta_prelimin ar_de_un_sistema_de_clasificación_de_vegetación_ 
para_el_Ecuador_Continental_proyecto_INEFAN_GE F-BIRF_y_EcoCiencia_Preliminary_ https://doi.org/10.13140/2.1.4520.9287

Simmers, I. (2003). Understanding water in a dry environment:Hydrological processes in arid and semiarid zones. IAH International Contributions to Hydrogeology 23. Publisher: A. A. Balkema. Retrieved from http://web.sahra.arizona.edu/swhydro/archive/V3_N2/d ept-inprint.pdf

Smith, T. M., \& Smith, R. L. (2007). Ecología (6 $6^{\text {th }}$ ed.). Madrid, España: Pearson Addison Wesley.

van Schaik, N. L. M. B., Schnabel, S., \& Jetten, V. G. (2008). The influence of preferential flow on hillslope hydrology in a semi-arid watershed (in the Spanish Dehesas). Hydrological Processes, 22(18), 3844-3855. https://doi.org/10.1002/hyp
Ward, R. C., \& Robinson, M. (2000). Principles of hydrology ( $4^{\text {th }}$ ed.). London, UK: McGraw-Hill Publishing Co.

Wohl, E., Barros, A., Brunsell, N., Chappell, N. A., Coe, M., Giambelluca, T., ..., Ogden, F. (2012). The hydrology of the humid tropics. Nature Climate Change, 2(9), 655-662. https://doi.org/10.1038/nclimate1556

Yatheendradas, S., Wagener, T., Gupta, H., Unkrich, C., Goodrich, D., Schaffner, M., \& Stewart, A. (2008). Understanding uncertainty in distributed flash flood forecasting for semiarid regions. Water Resources Research, 44(5), 1-17. https://doi.org/10.1029/2007WR005940 